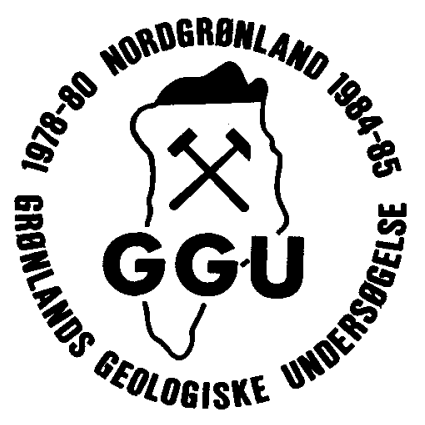

\title{
Cambrian platform - outer shelf relationships in the Nordenskiöld Fjord region, central North Greenland
}

\author{
J. R. Ineson and John S. Peel
}

Cambrian sequences around the head of Nordenskiöld Fjord, central North Greenland, preserve the transition from platform interior carbonates of the Ryder Gletscher Group (redefined) to outer shelf-slope and platform margin sequences assigned to the Brønlund Fjord and Tavsens Iskappe Groups. Study of this transition has allowed redefinition and integration of these two stratigraphic schemes. Shallow subtidal to intertidal, well-bedded carbonates of the platform interior grade north-eastwards into high-energy grainstones and algal boundstones of the platform margin complex. Platform foreslope facies show well-developed clinoform bedding and wedge out into dark carbonates and clastics of the outer shelf sequence.

J. R. I., British Antarctic Survey, Madingley Road, High Cross, Cambridge CB3 OET, U.K. Present address: University of London, Goldsmiths' College, New Cross, London SE14 6NW, U.K.

J. S. P., Grønlands Geologiske Undersøgelse, Øster Voldgade 10, DK-1350 Copenhagen K, Denmark.

Cambrian sediments are widespread in North Greenland, both in the largely undeformed shelf sequences which tend to outcrop in the southern part of the region, just north of the ice margin, and in the strongly folded deep-water trough sediments forming the northern coast region (a general stratigraphic summary is given by Peel, 1982). Platform carbonates of the Lower Cambrian Portfjeld Formation occur extensively in central and eastern areas. They form the lowest regionally recognised Cambrian unit, although sporadic exposures of shales, sandstones and carbonates which collectively can be referred to the Skagen Group of Friderichsen et al. (1982) occur at several localities from northern Wulff Land to north-eastern Peary Land beneath the Portfjeld Formation (Peel, 1982; Dawes \& Peel, 1984; Higgins \& Soper, 1985; Surlyk \& Ineson, 1987). The Portfjeld Formation is overlain by a sandstoneshale sequence which can be traced east-west across all of North Greenland. In eastern and central areas this sequence is ascribed to the Buen Formation but the terms Humboldt Formation and Dallas Bugt Formation are applied in Daugaard-Jensen Land and Inglefield Land, respectively (fig. 1).

In southern Peary Land (fig. 1), carbonate-dominated Cambrian sediments above the Buen Formation are assigned to the Brønlund Fjord and Tavsens Iskappe Groups (Peel, 1979; Ineson \& Peel, 1980, in press). The sedimentological evolution of this prograding complex is the subject of studies by Ineson $(1980,1985$; see also Surlyk \& Ineson, 1987). Sedi- 




Fig. 1. The Nordenskiöld Fjord region of central North Greenland showing the area of outcrop of sediments referred to the Brønlund Fjord, Tavsens Iskappe and revised Ryder Gletscher Groups (black). IF. Independence Fjord; GBSF, G. B. Schley Fjord.

ments assigned to the Brønlund Fjord Group occur throughout southern Peary Land from J. P. Koch Fjord, in the west, to the shores of Independence Fjord, in the east; less extensive, tectonically disturbed outcrops are known also from the G. B. Schley Fjord region, to the north-east (Christie \& Ineson, 1979; Ineson \& Peel, in press). The Tavsens Iskappe Group does not crop out farther to the east than central areas of southern Peary Land; neither group is represented to the south of Independence Fjord.

From aerial reconnaissance carried out in 1978 and 1979, it became clear that the Brønlund Fjord and Tavsens Iskappe Groups could be traced in outcrop westward across southern Freuchen Land (fig. 1), with little apparent change from the reference area around J. P. Koch Fjord. Hurst \& Peel (1979) had compared the basal part of the Cambrian carbonate sequence overlying the Buen Formation in southern Wulff Land to the Brønlund Fjord 
Group, but it was soon realised that the Cambrian carbonate sequence in this region could not be compared in detail with the Brønlund Fjord and Tavsens Iskappe Groups, as known from more eastern outcrops (Peel, 1980). The difference was emphasised with the proposal by Peel \& Wright (1985) of the name Ryder Gletscher Group for the Cambrian to Lower Ordovician(?) carbonate-dominated sequence in southern Warming Land and southern Wulff Land; a sequence corresponding closely in terms of age to the combined Brønlund Fjord and Tavsens Iskappe Groups of western Peary Land.

Due to the regional northerly dip, outcrops of the Cambrian shelf sequences of the Ryder Gletscher, Brønlund Fjord and Tavsens Iskappe Groups are soon covered to the north by succeeding Ordovician and Silurian strata. In consequence, the relationship between these units and deeper water trough sequences described from more northerly areas (Friderichsen et al., 1982; Surlyk \& Hurst, 1984) has been uncertain. Concurrent with the original description of the Brønlund Fjord Group, however, it was recognised that samples of dark, fossiliferous, Lower and Middle Cambrian carbonates from northern Nyeboe Land collected by P. R. Dawes in 1966 (for summary of references see Dawes \& Peel, 1984) were lithologically very similar to strata of the same age known from the Brønlund Fjord Group around J. P. Koch Fjord. This observation naturally lead to the speculation that strata of the Brønlund Fjord Group in some expression extended far beyond the typical area of southern Freuchen Land to southern Peary Land. The problem was partly solved when one of us (JSP) recognised the Aftenstjernes $\varnothing$ and Henson Gletscher Formations of the Brønlund Fjord Group in sections under study by A. K. Higgins and N. J. Soper at northern Navarana Fjord during 1984 (Higgins \& Soper, 1985). The basis for a correlation between the shallow shelf sequences to the south and the deeper water sequences to the north was thus established and has subsequently been developed in field studies during 1985 by Davis \& Higgins (1987) and Surlyk \& Ineson (1987).

The nature of the junction between the Brønlund Fjord and Tavsens Iskappe Groups and the Ryder Glétscher Group remained enigmatic. Peel \& Wright (1985) had traced the Ryder Gletscher Group as far east as Nordenskiöld Fjord recognising an abrupt, but at that time poorly understood transition into the Brønlund Fjord Group and Tavsens Iskappe Group sequences on the eastern side of the fjord. Among other details, they noted a very thick unit of pale weathering dolomite into which formations of both sequences intergraded. Peel \& Wright suggested that this unit might prove to be a new formation of the Brønlund Fjord Group in which guise it was illustrated (Peel \& Wright, 1985, fig. 2B).

During the 1985 field season it was possible to revisit the area around the head of Nordenskiöld Fjord and to develop a model elucidating the relationship between these three groups of Cambrian sediments. It is now recognised that this area marks the transition from shallow water platform sequences of the Ryder Gletscher Group in the west and south-west into the prograding platform margin and outer shelf slope deposits of the Brønlund Fjord and Tavsens Iskappe Groups, to the east and north-east. Elucidation of these relationships has promoted substantial revision of the Ryder Gletscher Group as originally defined by Peel \& Wright (1985), together with minor changes to the Brønlund Fjord and Tavsens Iskappe Groups as used by Ineson \& Peel (1980). 


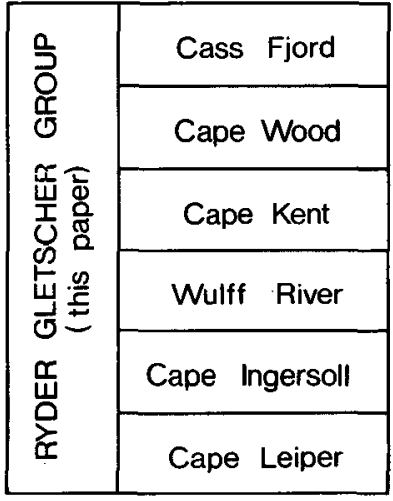

Inglefield Land

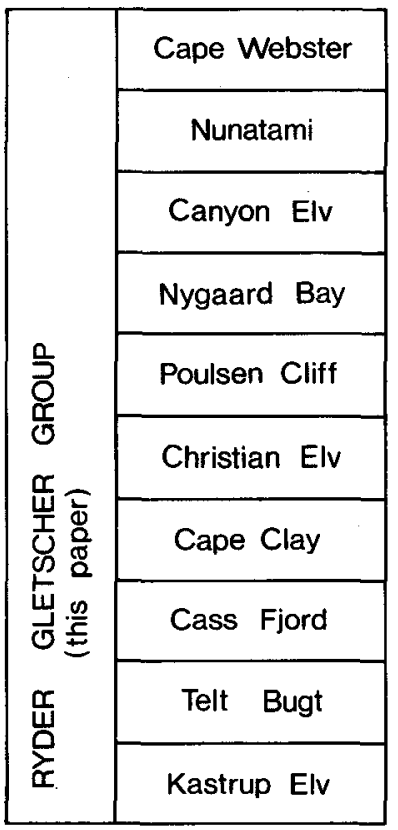

Washington Land

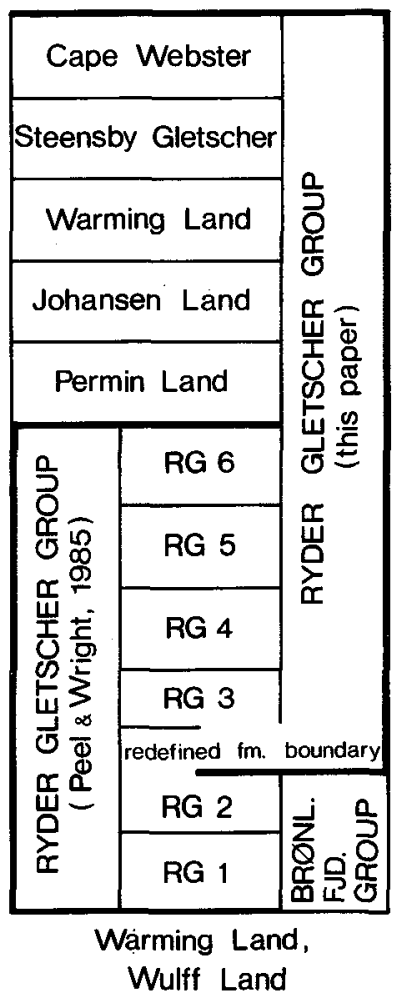

Wulff Land

\section{Ryder Gletscher Group}

The concept employed by Peel \& Wright (1985) in defining the Ryder Gletscher Group was that of a mapping unit of mainly carbonates, clearly capable of sub-division into a number of formations, lying between the sandstones and shales of the Buen Formation, below, and the striking, white quartzite of the Permin Land Formation (Bryant \& Smith, 1985), above (figs 2,3). Six formations (RG1-RG6) were indicated, but these were neither defined nor described in detail.

The upper four fifths of the Ryder Gletscher Group (total thickness $640 \mathrm{~m}$ ) were deposited under shallow-water platform or inner shelf conditions not unlike those prevailing also during deposition of the Lower to Middle Ordovician sequence overlying the Permin Land Formation, namely the Johansen Land, Warming Land and Steensby Gletscher and Cape Webster Formations (Sønderholm \& Due, 1985). It is now recognised that formation RG1 and most of formation RG2, as briefly described by Peel \& Wright (1985, p. 22), do not conform to this picture of a shallow-water platform sequence. Rather, they preserve sedimentary facies more typical of the outer shelf slope and platform margin sequences of the Brønlund Fjord and Tavsens Iskappe Groups.

Consequently, the Ryder Gletscher Group is redefined here from a genetic point of view (in contrast to the mapping approach employed by Peel \& Wright, 1985) as a sequence of platform interior carbonates and associated siliciclastic sediments, with the result that formation RG1 and a revised formation RG2 are transferred to the Brønlund Fjord Group (fig. 2). 


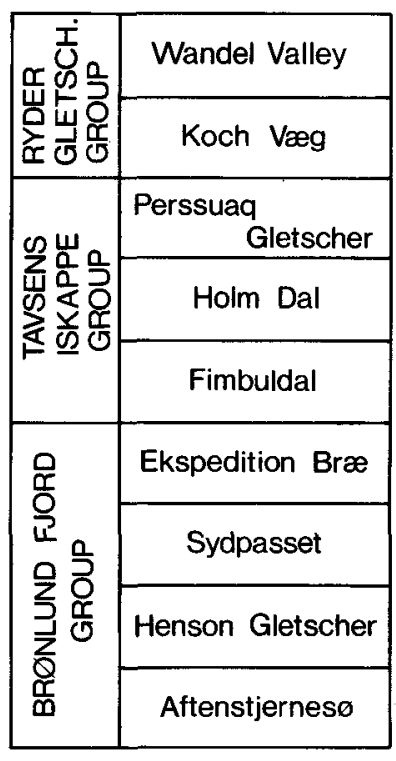

south-western

Peary Land

Fig. 2. Formational composition and distribution of the redefined Ryder Gletscher Group, compared to the original description by Peel \& Wright (1985).

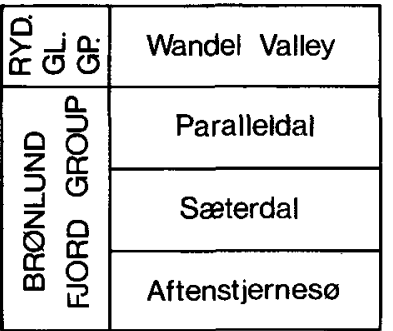

southern Peary Land

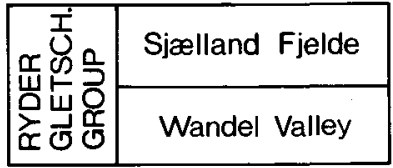

Kronprins Christian Land

In the type area of southern Warming Land and southern Wulff Land, the upper limit of the Ryder Gletscher Group is now drawn at the top of the Cape Webster Formation (fig. 2). The Ryder Gletscher Group is also extended to include a large number of formations in North and North-West Greenland deposited in similar shallow-water platform environments (fig. 2). Among these, the Koch Væg Formation of the southern J. P. Koch Fjord area, originally formation T4 of the Tavsens Iskappe Group (Ineson \& Peel, 1980), is also now assigned to the Ryder Gletscher Group (fig. 2).

The six formations (RG1-RG6) recognised by Peel \& Wright (1985) within the original Ryder Gletscher Group are still accepted, even though the lower two (RG1 and RG2) are not retained within the redefined Ryder Gletscher Group. One minor change, however, is proposed to this original sub-division to better rationalise the revised picture of sedimentary relationships. Peel \& Wright (1985) arbitrarily drew the top of formation RG2 at the top of a prominent, dark grey weathering, dark grey, burrow-mottled dolomite which forms a conspicuous marker horizon from southern Nares Land, in the east, to Warming Land, in the west, largely on account of its colour contrast with overlying very pale-weathering dolomites assigned to formation RG3 (fig. 4A). This dark-weathering unit is conspicuous in fig. 6 of Hurst \& Peel (1979) in strata in southern Wulff Land at that time referred to the 'Brønlund Fjord Group Wandel Valley Formation'. The same dark-weathering unit is also evident in fig. 2A of Peel \& Wright (1985) where it forms the top of formation RG2 as illustrated.

The dark-weathering burrow-mottled dolomite is identical in lithology with thin units of darker dolomite occuring within the dominant, very pale-weathering dolomites of formation RG3. In consequence, the unit is here transferred from formation RG2 to formation RG3 and the top of the former formation is now drawn at the base of the grey burrow-mottled dolomite and not at the top, as previously envisaged by Peel \& Wright (1985). Thus, forma- 
tions RG1 and RG2 (redefined) in their entirety were deposited in the same general depositional environment as the Brønlund Fjord Group, to which they are now transferred (figs 2, 3).

\section{Ryder Gletscher Group \\ redefined}

History. See Peel \& Wright (1985) and previous discussion.

Type area. The area around Ryder Gletscher in south-west Wulff Land and south-east Warming Land (see Peel \& Wright, 1985 and Sønderholm \& Due, 1985 for description of constituent formations in the type area of the group).

Dominant lithology. A series of platform interior carbonate rocks, principally dolomites in the type area, and associated siliciclastic sediments (see Peel \& Wright, 1985; Sønderholm \& Due, 1985).

Thickness. Up to about $1100 \mathrm{~m}$ in the type area.

Boundaries. In the type area, dark, burrow-mottled dolomite forming the basal unit of formation RG3 (revised) overlies cross-bedded dolomite grainstones of formation RG2 (revised) of the Brønlund Fjord Group with apparent conformity. At the top of the Ryder Gletscher Group, dolomites of the Cape Webster Formation are conformably overlain by limestones of the Gonioceras Bay Formation of the Morris Bugt Group (Sønderholm \& Due, 1985).

Distribution and subdivision. From Inglefield Land in the west to Kronprins Christian Land in the east (fig. 2).

Age. Early Cambrian - Middle Ordovician.

\section{Brønlund Fjord and Tavsens Iskappe Groups}

As noted above, formations RG1 and RG2 (revised) of Peel \& Wright (1985) are now placed within the Brønlund Fjord Group, while the Koch Væg Formation (formerly formation T4 of the Tavsens Iskappe Group) is transferred to the redefined Ryder Gletscher Group (fig. 2).

Peel \& Wright (1985, p. 23) commented that the Henson Gletscher Formation attained a maximum thickness of about $120 \mathrm{~m}$ in south-western Freuchen Land and that the overlying Sydpasset Formation reached a maximum observed thickness of about $35 \mathrm{~m}$. This statement is now revised. A unit of dark nodular dolomites and dolomite grainstones some $30 \mathrm{~m}$ thick which was assigned to the Henson Gletscher Formation in the section measured by Peel \& Wright (1985) in south-west Freuchen Land, is now referred to the overlying Sydpasset For- 
mation. For further description, see Christiansen et al. (1987). The Sydpasset Formation thickens greatly to the west as it grades laterally into formation RG2 of the Brønlund Fjord Group at the head of Nordenskiöld Fjord (see fig. 3 and discussion, below).

Peel \& Wright (1985, p. 24) also considered that the Tavsens Iskappe Group could be traced through a series of imperfect cliff top exposures for some kilometres to the south-west of the head of Nordenskiöld Fjord, into the land area south of Nares Land (fig. 1). Following further study, these cliff top outcrops are now referred to the Ryder Gletscher Group, the outcrop of which is thus extended eastward across Nordenskiöld Fjord and into southwestern Freuchen Land. The Tavsens Iskappe Group is well exposed around the glacier at the head of Navarana Fjord in south-eastern Freuchen Land but the precise relationship between these strata and stratigraphically equivalent parts of the Ryder Gletscher Group is obscured by ice cover in central southern Freuchen Land.

\section{Platform - outer shelf relationships}

In the Peary Land to Freuchen Land area, shelf sedimentation during the Cambrian was strongly influenced by the tectonic interplay between the subsiding North Greenland trough and the uplifted eastern (Caledonide) margin of North Greenland (Surlyk \& Hurst, 1984; Ineson, 1985). The Brønlund Fjord and Tavsens Iskappe Groups of this area represent outer shelf - slope and platform margin environments, and record a history of episodic subsidence within a framework of overall regression (Ineson, 1985). This regressive sedimentation pattern resulted in progressive exposure of the shelf in eastern areas of North Greenland from the late Early Cambrian to the earliest Ordovician and the production of a regionally developed unconformity beneath the subsequently deposited Wandel Valley Formation (late Early Middle Ordovician) of the Ryder Gletscher Group (Ineson \& Peel, 1980). The regression was also marked by an influx of siliciclastic detritus in the Late Cambrian and Early Ordovician (Perssuaq Gletscher Formation of the Tavsens Iskappe Group; Permin Land Formation of the Ryder Gletscher Group). Platform interior carbonates in this eastern part of the Cambrian shelf are only represented by the Koch Væg Formation of the Ryder Gletscher Group around the head of J. P. Koch Fjord.

In contrast to this unstable, regressive style of sedimentation, most of the CambroOrdovician succession of western North Greenland is a conformable sequence of platform carbonates and shallow-water siliciclastic sediments (the redefined Ryder Gletscher Group) reflecting uniform subsidence of a stable shelf. The transition between these two contrasting regimes is exposed around the head of Nordenskiöld Fjord (figs 1, 3). West of the Nordenskiöld Fjord region, platform carbonates of the Ryder Gletscher Group dominate the succession and overlie a thin outer shelf to platform margin sequence (c. $145 \mathrm{~m}$ in thickness in southern Wulff Land), assigned to formations RG1 and RG2 of the Brønlund Fjord Group (figs 2, 3).

Formations RG1 and RG2 together represent a 'shoaling', shallowing-upward cycle, from storm-dominated carbonate ramp (outer shelf) to slope and platform margin. In the type area, the carbonate ramp sediments of RG1 are mainly thinly interbedded skeletal intraclastic limestones and bioturbated siltstones; storm influence is indicated by hummocky cross-stratification in lime grainstone beds. RG2 consists essentially of a lower succession of dolomitised carbonate turbidites and mass-flow deposits which grade up into an upper unit 


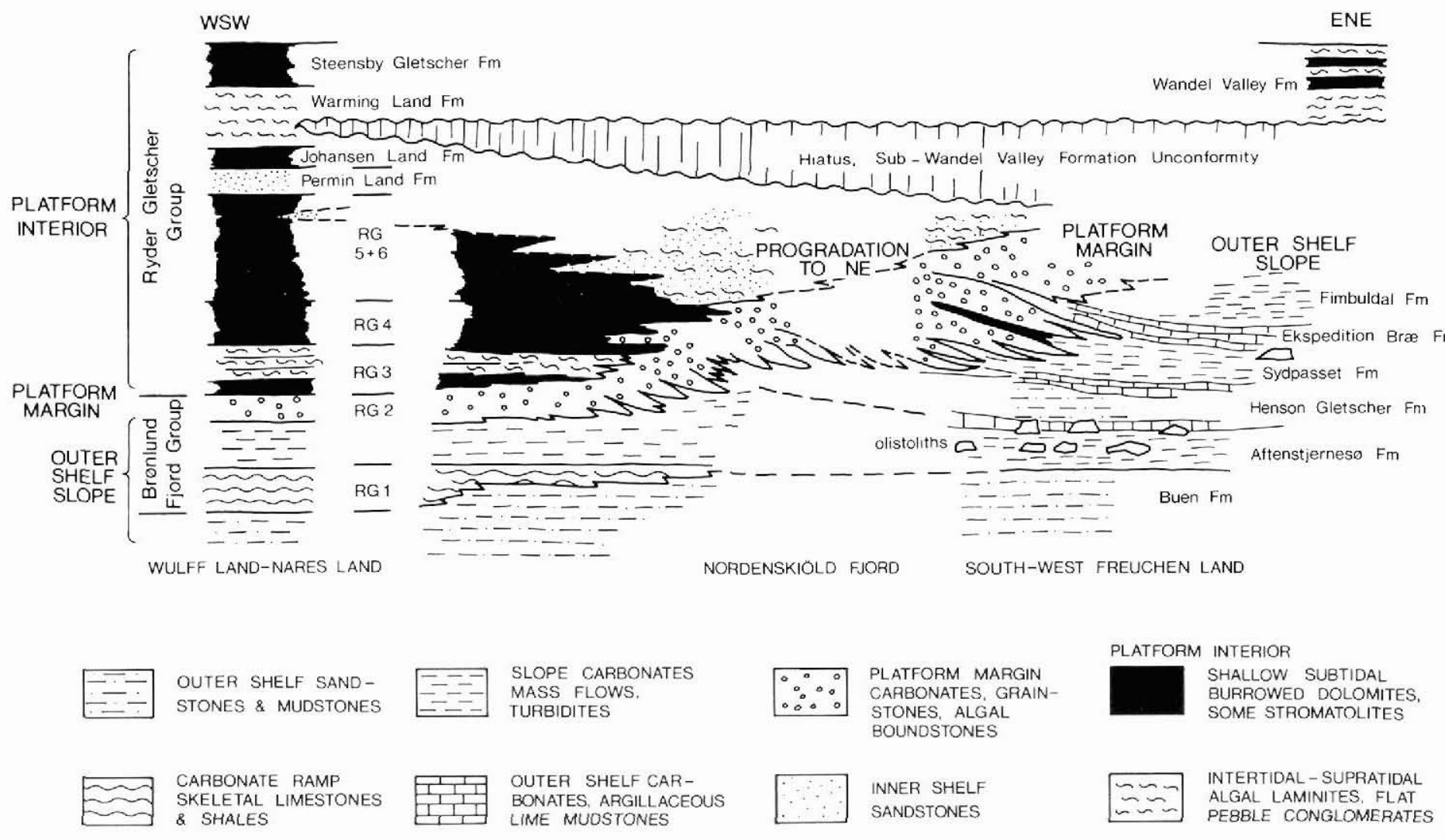

Fig. 3. Schematic cross-section showing the relationships between Cambro-Ordovician platform and outer shelf strata in the area around the head of Nordenskiöld Fjord, central North Greenland. RG1 and RG2 are informally described formations of the Brønlund Fjord Group; RG3 and RG6 are informally described formations of the Ryder Gletscher Group. 
of pale carbonate grainstones showing trough and hummocky cross-stratification; flat, low angle stratification of probable beach origin was observed in places at the top of the formation. RG2 represents the slope and high energy outer margin of a shallow-water platform. This shallowing-upward cycle in RG1 and RG2 is suggestive of lateral progradation of a shallow-water platform, a characteristic feature of the Brønlund Fjord and Tavsens Iskappe Groups farther to the east (Ineson 1980; 1985). In the type area around J. P. Koch Fjord, the Brønlund Fjord and Tavsens Iskappe Groups are together about $900 \mathrm{~m}$ thick; outer shelf deposits make up about two-thirds of this thickness. In contrast to this eastern sequence, however, outer shelf deposits assigned to the Brønlund Fjord Group are relatively poorly developed (less than $60 \mathrm{~m}$ ) in southern Wulff Land and Warming Land. Platform foreslope primary dips are not observed and diachronism of the platform margin is not demonstrable in this area. This suggests a low-relief transition from platform to outer shelf and rapid progradation of shallow-water environments.

The overlying formations RG3 to RG6 of the Ryder Gletscher Group in central areas of North Greenland record sedimentation in shallow-water, restricted platform environments (fig. 3). These formations are characterised by dark burrow-mottled dolomites, silty lime mudstones and flat-pebble conglomerates, and mud-cracked stromatolitic and cryptalgal dolomites; cross-bedded, wave-rippled and mud-cracked sandstones and siltstones are present in the upper levels of the group. Contemporaneous deeper water carbonates occur to the north of the Ryder Gletscher Group outcrop, in northern Nyeboe Land and northern Wulff Land (Higgins \& Soper, 1985; Surlyk \& Ineson, 1987) but the transition from the Ryder Gletscher Group to these sediments is hidden beneath younger strata.

The Cambro-Ordovician shelf sequence shows little lateral variation across Warming Land, southern Wulff Land and the western part of the land area south of Nares Land (fig. 4A). As Nordenskiöld Fjord is approached, however, the pale massive carbonates of the platform margin which form the upper part of the revised formation RG2 (Brønlund Fjord Group) thicken markedly and become diachronous, prograding towards the north or northnorth-east (figs 3, 5). Platform margin rocks are often structureless, coarsely recrystallised dolomites but they include relict cross-bedded, ooidal intraclastic and oncolitic grainstones with thin developments of columnar stromatolites and algal laminites. On the western side of Nordenskiöld Fjord, this platform margin complex within formation RG2 includes a unit (c. $200 \mathrm{~m}$ thick) composed largely of algal boundstones, with subordinate carbonate grainstones. The boundstones are composed of clotted and plumose algae which resemble $R e$ nalcis but are several times larger than most records of this form (Pratt, 1984). The algae show irregular stromatolitic and cavity-filling, pendant growth forms (fig. 6). Bedding is generally wavy and laterally impersistent, or sub-horizontal. The unit has a distinctive irregularly banded appearence in cliff sections; mounds up to $2 \mathrm{~m}$ in diameter and $0.5 \mathrm{~m}$ in height were observed. Archaeocyathans occur locally, indicating a probable Early Cambrian age; they are otherwise known from North Greenland only from the Paralleldal Formation of southern Peary Land (fig. 2) where they occur in a similar platform margin setting (Debrenne \& Peel, 1986; Ineson \& Peel, in press). On the east side of Nordenskiöld Fjord, this platform margin complex exhibits spectacular foreslope primary dips which emphasise the general progradation of the platform margin to the north-north-east (fig. 5).

It is this greatly expanded upper portion of formation RG2 which is the dominant geological unit in $_{j}$ the cliffs surrounding the head of Nordenskiöld Fjord and which forms the possible new formation of the Brønlund Fjord Group to which Peel \& Wright (1985, p. 17) al- 

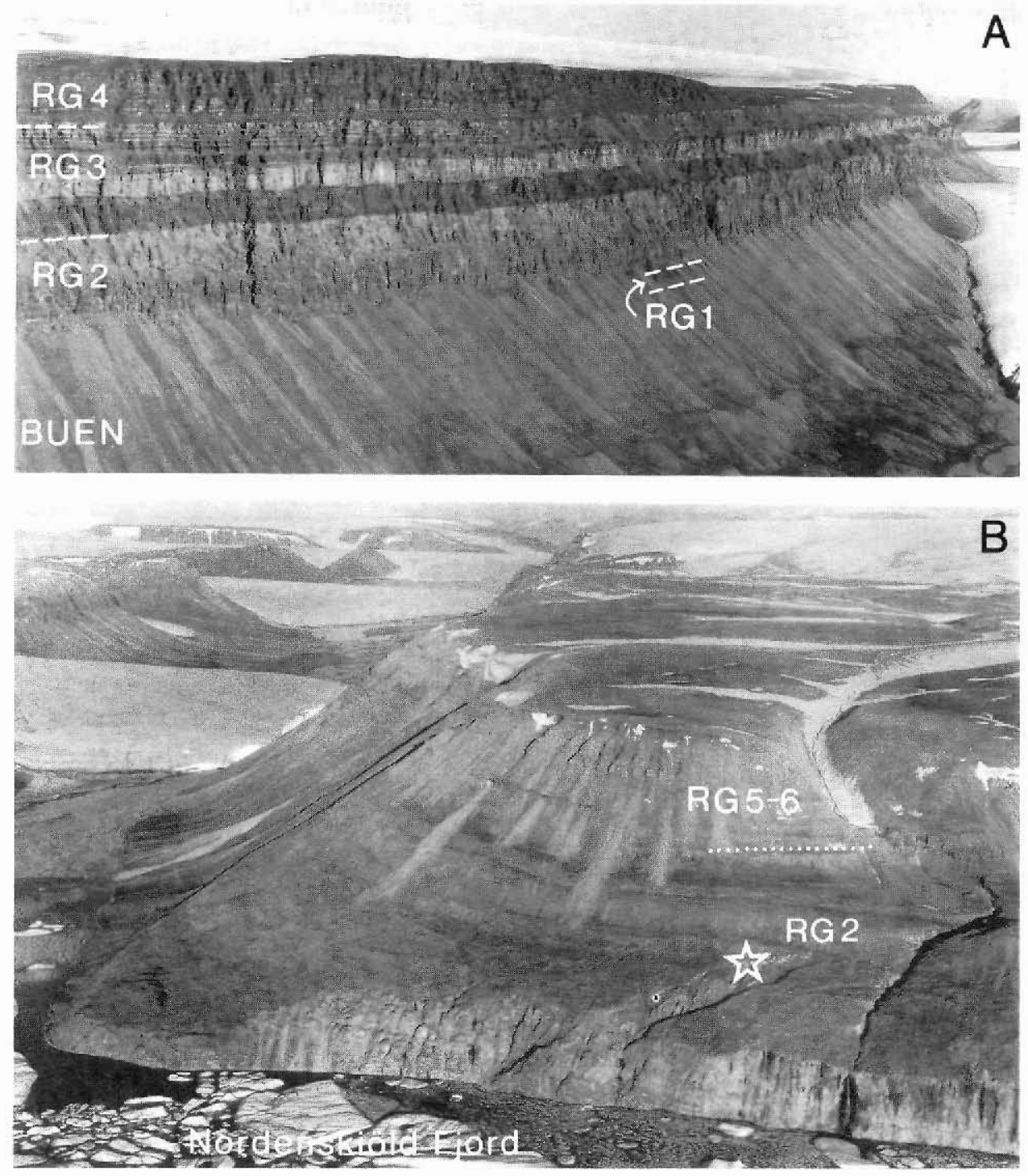

Fig. 4. The Brønlund Fjord and Ryder Gletscher Groups in the land area south of Nares Land. For location of photographs see fig. 1. A: carbonates of the Brønlund Fjord Group (RG1 and RG2) and the Ryder Gletscher Group (RG3 and RG4) showing their typical development. Shales and sandstones of the Buen Formation form the talus covered slopes. The cliff top is approximately $600 \mathrm{~m}$ above sea level. The unit of burrow-mottled dolomite forming the distinctive dark band at the base of formation RG3 was previously placed within formation RG2 by Peel \& Wright (1985). B: platform interior strata of formations RG5 and RG6 of the Ryder Gletscher Group overlying the platform margin complex of formation RG2 of the Brønlund Fjord Group; western side of the head of Nordenskiöld Fjord. The cliff top is approximately $700 \mathrm{~m}$ above sea level. The pale laminated dolomites and dark, burrow-mottled dolomites characteristic of formations RG3 and RG4 in more westerly outcrops find their equivalence in the upper part of formation RG2. The star marks the location of algal boundstones illustrated in fig. 6 . 
luded. In the eastern wall of the fjord, this unit overlies the dark, recessive Henson Gletscher Formation (fig. 5) and, farther east, is equivalent, in part, to the Sydpasset Formation (fig. 3). To the south, and as far east as the western wall of Jungersen Gletscher, the same pale platform margin carbonates cap the cliffs, overlying somewhat darker carbonates forming the lower part of formation RG2; these lower carbonates are evidently laterally continuous with the Aftenstjernesø Formation, which is clearly recognisable in all outcrops to the east of the Nordenskiöld Fjord - Jungersen Gletscher line. Thus, in fig. 2B of Peel \& Wright (1985), a panorama across the entrance to Jungersen Gletscher, units at that time assigned to the possible new formation and the Aftenstjernes $\emptyset$ Formation on the western side of the glacier are now referred to formation RG2 of the Brønlund Fjord Group. Thin, dark wisps at the junction between these two formerly recognised units probably represent the feather edge of the Henson Gletscher Formation. To the east of the glacier, in the same fig. 2B, the Henson Gletscher Formation overlies the Aftenstjernesø Formation. A thin, dark weathering unit at the base of the Aftenstjernes $\emptyset$ Formation represents the continuation of formation RG1 which is also present, but not discernible in the photograph, in the cliffs to the west of the glacier.

Strata assigned to formations RG5 and RG6 of the Ryder Gletscher Group are well exposed but generally inaccessible in the cliffs along both sides of Nordenskiöld Fjord, immediately north-west of the head of the fjord. The pale cryptalgal laminites and dark burrowmottled subtidal dolomites characteristic of formations RG3 and RG4 farther to the west are not conspicuous, however, as these platform interior facies wedge out eastwards into the diachronous platform margin complex of formation RG2 of the Brønlund Fjord Group (fig. 3). Hence, formations RG3 and RG4 are not recognised at the head of Nordenskiöld Fjord, finding their equivalent in the upper part of the sequence assigned to RG2. Furthermore, it has not been possible to recognise the mapping horizon used to separate formation RG5 from formation RG6 in the Warming Land to Wulff Land region, although the general character of accessible exposures is consistent with the litholgies of both these formations.

As noted above, impersistent exposure along the margin of the permanent ice cap in Freuchen Land prevents clarification of the precise relationship between the platform margin complex exposed at Nordenskiöld Fjord (here assigned to the Brønlund Fjord Group) and the Tavsens Iskappe Group farther to the north-east. It is evident, however, that the Fimbuldal Formation of the Tavsens Iskappe Group passes laterally westward into the platform margin complex of formation RG2, in similar fashion to the Sydpasset Formation of the Brønlund Fjord Group. The Perssuaq Gletscher Formation of the Tavsens Iskappe Group represents a more direct continuation of the prograding platform margin complex preserved in the upper part of RG2 (Ineson, 1985). Intervening outer shelf carbonates and shales of the Holm Dal Formation probably wedge out toward the platform margin in south-western Freuchen Land in similar fashion to the Henson Gletscher and Ekspedition Bræ Formations of the Brønlund Fjord Group.

It is clear from fig. 3 that the area around the head of Nordenskiöld Fjord preserves an important transition between two contrasting depositional regimes. To the west and southwest, a shallow-water stable carbonate platform was maintained with little variation throughout the Cambrian, reflecting steady, uniform subsidence. To the east and north-east, the Brønlund Fjord and Tavsens Iskappe Groups record a history of episodic subsidence within a framework of overall regression (Ineson, 1985). The thick, diachronous, platform margin complex at the head of Nordenskiöld Fjord probably marks a 'hinge zone', during 

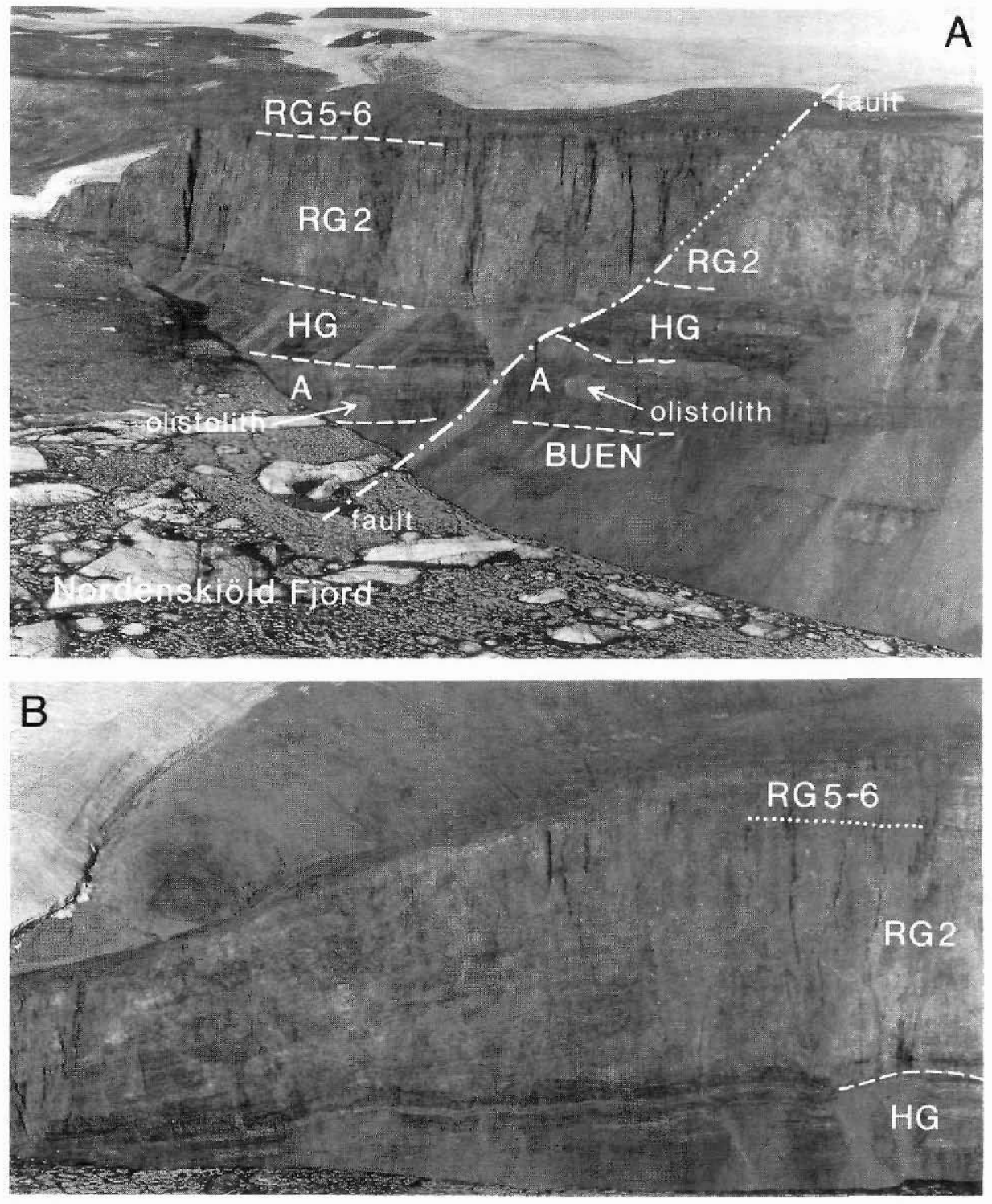

Fig. 5. Cambrian platform margin relationships in south-western Freuchen Land, eastern side of the head of Nordenskiöld Fjord. For location see fig. 1. A: platform interior carbonates of formation RG5 and RG6 of the Ryder Gletscher Group overlying strongly prograding platform margin dolomites of formation RG2 (fig. 5B) of the Brønlund Fjord Group. The latter formation overlies dark, recessive outer shelf carbonates and sandstones of the Henson Gletscher Formation (HG) of the Brønlund Fjord Group. Slope carbonates of the Aftenstjernesø Formation (A) of the Brønlund Fjord Group contain carbonate olistoliths in association with paler-weathering mass flow deposits. Lower, largely talus covered slopes are formed by outer shelf sandstones and mudstones of the Buen Formation. Height of cliff is approximately $700 \mathrm{~m}$. B: platform margin dolomites of formation RG2 of the Brønlund Fjord Group showing well developed foreslope clinoforms prograding to the north-east and seen in oblique, northsouth section. For explanation see fig. 5A; the illustrated cliff face (maximum height about $300 \mathrm{~m}$ ) lies to the extreme left in fig. 5A. 

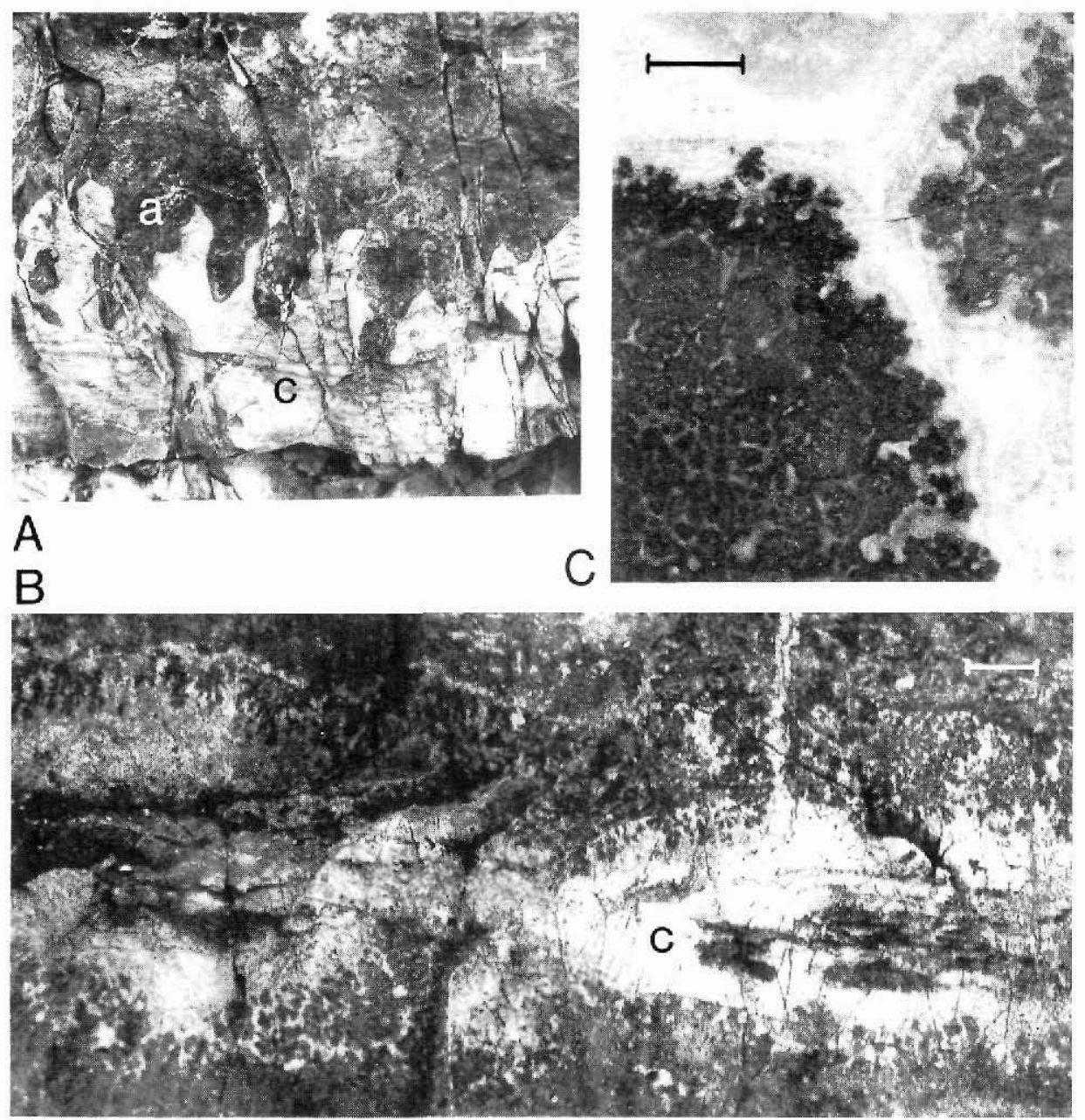

Fig. 6. Algal structures in formation RG2 of the Brønlund Fjord Group, western side of the head of Nordenskiöld Fjord (see fig. 5B). Note the scarcity of geopetal lime mud in the illustrated spar-filled cavities, reflecting the high-energy, current-swept environment at the platform margin. A: pendulous, stalactitic growths of clotted, Renalcis-like algae (a) encrusting a cavity roof. The cavity has subsequently been occluded by banded, fibrous, early diagenetic carbonate (c). B: cement-filled cavity of pale carbonate (c) within algal boundstone. Note the clotted, irregular growth form at the cavity floor and the plumose, dendritic, Epiphyton-like form encrusting both the cavity floor and roof. C: clotted, locally chambered or saccate, Renalcis-like algae, rimmed by fibrous carbonate cement. Geopetal internal sediment between cement bands located elsewhere in the same sample (not illustrated) indicates synsedimentary cementation. Bar: $1 \mathrm{~cm}$.

the Early Cambrian at least, between the stable platform to the south-west and the more dynamic system to the north-east. 


\section{References}

Bryant, I. D. \& Smith, M. P. 1985: Lowermost Ordovician sandstones in central North Greenland. Rapp. Grønlands geol. Unders. 126, 25-30.

Christiansen, F. G., Nøhr-Hansen, H. \& Nykjær, O. 1987: The Cambrian Henson Gletscher Formation: a mature to postmature hydrocarbon source rock sequence from North Greenland. Rapp. Gronlands geol. Unders. 133, 141-157.

Christie, R. L. \& Ineson, J. R. 1979: Precambrian Silurian geology of the G. B. Schley Fjord region, eastern Peary Land, North Greenland. Rapp. Grønlands geol. Unders. 88, 63-71.

Dawes, P. R. \& Peel, J. S. 1984: Biostratigraphic reconnaissance in the Lower Palaeozoic of western North Greenland. Rapp. Grønlands geol. Unders. 121, 19-51.

Davis, N. C. \& Higgins, A. K. 1987: Cambrian-Lower Silurian stratigraphy in the fold and thrust zone between northern Nyeboe Land and J. P. Koch Fjord, North Greenland. Rapp. Grønlands geol. Unders. 133, 91-98.

Debrenne, F. \& Peel, J. S. 1986: Archaeocyatha from the Lower Cambrian of Peary Land, central North Greenland. Rapp. Grønlands geol. Unders. 132, 39-50.

Friderichsen, J. D., Higgins, A. K., Hurst, J. M., Pedersen, S. A. S., Soper, N. J. \& Surlyk, F. 1982: Lithostratigraphic framework of the Upper Proterozoic and Lower Palaeozoic deep water clastic deposits of North Greenland. Rapp. Grønlands geol. Unders. 107, $20 \mathrm{pp}$.

Higgins, A. K. \& Soper, N. J. 1985: Cambrian-Lower Silurian slope and basin stratigraphy between northern Nyeboe Land and western Amundsen Land, North Greenland. Rapp. Grønlands geol. Unders. 126, 79-86.

Hurst, J. M. \& Peel, J. S. 1979: Late Proterozoic(?) to Silurian stratigraphy of southern Wulff Land, North Greenland. Rapp. Grønlands geol. Unders. 91, 37-56.

Ineson, J. R. 1980: Carbonate debris flows in the Cambrian of south-west Peary Land, eastern North Greenland. Rapp. Grønlands geol. Unders. 99, 43-49.

Ineson, J. R. 1985: The stratigraphy and sedimentology of the Brønlund Fjord and Tavsens Iskappe Groups (Cambrian) of Peary Land, eastern North Greenland. Unpubl. Ph.D. thesis, University of Keele, 310 pp.

Ineson, J. R. \& Peel, J. S. 1980: Cambrian stratigraphy in Peary Land, eastern North Greenland. Rapp. Grønlands geol. Unders. 99, 33-42.

Ineson, J. R. \& Peel, J. S. in press: Cambrian shelf stratigraphy of the Peary Land region, central North Greenland. Bull. Grønlands geol. Unders.

Peel, J. S. 1979: Cambrian-Middle Ordovician stratigraphy of the Adams Gletscher region, south-west Peary Land, North Greenland. Rapp. Grønlands geol. Unders. 88, 29-39.

Peel, J. S. 1980: Cambrian and Ordovician geology of Warming Land and southern Wulff Land, central North Greenland. Rapp. Grønlands geol. Unders. 101, 55-60.

Peel, J. S. 1982: The Lower Paleozoic of Greenland. Mem. Can. Soc. Petrol. Geol. 8, 309-330.

Peel, J. S. \& Wright, S. C. 1985: Cambrian platform stratigraphy in the Warming Land-Freuchen Land region, North Greenland. Rapp. Grønlands geol. Unders. 126, 17-24.

Pratt, B. R. 1984: Epiphyton and Renalcis diagenetic microfossils from calcification of coccoid bluegreen algae. J. Sedim. Pet. 54, 948-971.

Surlyk, F. \& Hurst, J. M. 1984: The evolution of the early Paleozoic deep-water basin of North Greenland. Bull. geol. Soc. Am. 95, 131-154.

Surlyk, F. \& Ineson, J. R. 1987: Aspects of Franklinian shelf, slope and trough evolution and stratigraphy in North Greenland. Rapp. Grønlands geol. Unders. 133, 41-58.

Sønderholm, M. \& Due, P. H. 1985: Lower and Middle Ordovician platform carbonate lithostratigraphy of Warming Land, Wulff Land and Nares Land, North Greenland. Rapp. Grønlands geol. Unders. 126, 31-46. 